\title{
Environmental Regulation and Green Total Factor Productivity: Evidence from China's Marine Economy
}

\author{
Qin Lingui ${ }^{1}$, Miao Xu' ${ }^{1}$, Tan Juan² ${ }^{2}$ Li Shuaishuai ${ }^{2 *}$ \\ ${ }^{1}$ College of Economics and Management, Shenyang Agricultural University, Shenyang 110866, China \\ ${ }^{2}$ School of Management, Shandong University, Jinan, 250100, China
}

Received: 22 February 2021

Accepted: 21 April 2021

\begin{abstract}
This study investigates the effect of environmental regulation on green total factor productivity (GTFP) of marine economy in China. Environmental regulation can reduce environmental pollution, and it is the key to sustainable development, but we scarcely know its effects on marine economy. Although environmental regulation increases the cost of economic operation and reduces profits, it also can improve the productivity through stimulating more innovation activities. Therefore, the net effect of environmental regulation on productivity depends on the relative size of the two competitive effects. We present the following evidence on the basis of marine economy in China's coastal provinces. (1) The GTFP of marine economy shows an upward trend. (2) Environmental regulation from investment and cost perspectives has a positive effect on GTFP of marine economy in the long term but not the short term, which supports the Porter hypothesis. (3) Environmental regulation has a single threshold effect on GTFP with environmental regulation, economic development level, and technological level as the threshold variable, respectively. The influence on GTFP can be significantly positively after crossing the threshold value. This study provides timely evidence and important policy implications for achieving a win-win situation between environmental protection and economic development through environmental regulation.
\end{abstract}

Keywords:environmental regulation, marine economy, green total factor productivity, sustainability

\section{Introduction}

Studies of environmental economy have long recognized the role of environmental regulation in improving environmental quality [1-4]. In terms of economic effects, the Porter hypothesis holds that

*e-mail: lukali@sdu.edu.cn

appropriate environmental regulation can stimulate innovation and promote economic development [1]. If the Porter hypothesis is true, this means that a win-win situation for environmental protection and economic development can be achieved through environmental regulation. In an emerging economy such as China, environmental improvement is as important as economic development. Several studies investigate the applicability of the Porter hypothesis in China and two 
different conclusions have been drawn. One view is that environmental regulation hurts economic development because it incurs additional environmental costs [5]. The other view is that environmental regulation improves economic development because it facilitates innovation [6,7]. However, in China, marine economy is also an important part of the green economy [8], and thus, we know little about the relationship between environmental regulation and the marine economy. Therefore, in this study, we investigate the effect of environmental regulation on green total factor productivity (GTFP) of marine economy in China.

We examine the impact of environmental regulation on China's marine economy in order to verify the applicability of the Porter hypothesis. Although the applicability of the Porter hypothesis has been verified in many industries, marine economy remains an interesting topic. Using the unique sample of China's marine economy, we examine the actual impact of environmental regulation on the marine economy.

Our study is important for two reasons. First, China's outputs from the marine economy account for approximately $10 \%$ of its GDP, with an average annual growth rate of nearly $10 \%$, thus, the marine economy plays an important role in the economic sustainability of China [8]. However, economic development and anthropogenic activities have damaged marine environments. The Bulletin on China's Marine Ecological Environment in 2018 points out that China's marine environments are facing various problems, such as the vulnerability of the marine ecosystem and overall poor coastal water quality [9]. In such a situation, it is important to examine the impact of environmental regulation on the marine economy. We focus on the marine economy because it is vital not only to environmental protection but also to economic growth. Second, although the Porter hypothesis holds that environmental regulation is conducive to innovation and economic growth, environmental regulation increases the cost of economic operation, crowds out innovation investment, and reduces profits. In this study, the impact of environmental regulation on the marine economy is considered an empirical question.

Existing studies hold two views on the impact of environmental regulation on economic development. From the static perspective, environmental regulation has the compliance cost effect on economic development $[10,11]$. First, environmental regulation increases the cost of economic operation and crowds out investment in innovation and expanded reproduction [12, 13]. Second, the extra cost incurred by environmental regulation poses an industrial barrier to small-andmedium sized enterprises [14], so environmental regulation hurts competition. Third, environmental cost may bring about rent-seeking behaviors [15], thus reducing the efficiency of resource allocation and effectiveness of environmental policies. Hence, environmental regulation is not conducive to economic development from the static perspective.
From the dynamic perspective, environmental regulation has the innovation compensation effect on economic development $[2,16]$, that is, environmental regulation can promote economic development by promoting innovation. Porter and Linde argued that appropriate environmental regulation can stimulate more technological and managerial innovations of enterprises and scientific research institutions, thus optimizing resource allocation, increasing economic output, and compensating for the cost of environmental regulation in the long run [1]. Hence, environmental regulation can achieve a win-win situation between environmental protection and economic growth from the dynamic perspective [17-19].

We argue that the key to a win-win situation between environmental protection and economic growth lies in the magnitude of the innovation compensation effect, that is, whether environmental regulation can promote economic development. Most existing studies contend that the innovation compensation effect of environmental regulation lags behind the compliance cost effect [20,21], specifically, environmental regulation inhibits economic development in the short run but promotes economic development by stimulating innovation in the long run.

For marine economy, the degree and quality of green development are important indicators of its longterm sustainability, and green total factor productivity (GTFP) is an important indicator of sustainable development and green development [22, 23]. Hence, we mainly discuss the impact of environmental regulation on the GTFP of marine economy.

Based on existing studies [1, 10, 16, 20-23], we present the following hypotheses, in the short run, environmental regulation increases the costs of the marine economy and is not conducive to the development of marine economy. As environmental regulation is implemented regularly and society places more importance on it, it can stimulate more innovation activities, thus improving the GTFP of the marine economy in the long run.

Moreover, existing studies show that the impact on economic development varies depending on the intensity of environmental regulation. However, we do not aim to merely verify the non-linear relationship between environmental regulation and the marine economy. In China, there is GDP competition across local governments $[24,25]$, whether officials are promoted is positively correlated with regional economic growth, so the intensity of local environmental regulation is affected by economic development level. The more developed a region's economy is, the more importance the region gives to environmental protection. Hence, environmental regulation is more likely to affect the GTFP of the marine economy. In less developed regions, environmental regulation may be loosened to promote GDP growth, and it has less impact on the GTFP. The magnitude of the innovation compensation effect is also affected by the technological level. The higher the 
technological level is, the stronger the innovation ability is, and the more significantly environmental regulation improves the GTFP of marine economy. Therefore, we assume that the impact of environmental regulation on the GTFP of marine economy is differentiated depending on the intensity of environmental regulation, the economic development level, and the technological level, respectively.

To test the assumption, we analyse panel data on the marine economy of China's 11 provincial-level coastal regions from 2001 to 2016 and draws a conclusion that is in line with the assumption. The empirical conclusions can be summarized as follows.

First, the GTFP of China's marine economy is measured in terms of the Malmquist-Luenberger index of undesirable output. Undesirable output is measured with regard to two features (i.e. resource consumption and environmental pollution) to overcome the deviation from the singleness of an indicator. The results show that the GTFP of marine economy considering undesirable output is higher than that without considering undesirable output.

Second, from the perspectives of investment and cost, we construct environmental regulation indicators using the location entropy method, respectively. To verify the temporal effect of environmental regulation on GTFP, we analyse the impact of environmental regulation in the current period and the lag period on the GTFP of marine economy, and the SYS-GMM is used to relieve the potential endogeneity. The results show that the impact of the environmental regulation measured from different perspectives on GTFP is basically consistent. Environmental regulation in the current period can negatively affect GTFP, whereas environmental regulation in the lag periods can significantly positively affect GTFP. In other words, environmental regulation shows compliance cost effect on the GTFP of the marine economy in the short run but innovation compensation effect in the long run.

Third, using the intensity of environmental regulation, the economic development level, and technological level as threshold variable, we analyse the impact of environmental regulation on GTFP using the threshold model. The results show that a threshold effect exists in the impact of environmental regulation on GTFP. When the intensity of environmental regulation, economic development level, or technological level is low, the impact of environmental regulation on GTFP is insignificant or significantly negative. When environmental regulation, economic development level, or technological level crosses the threshold value, environmental regulation can significantly positively affect GTFP. In other words, high intensity of environmental regulation, high economic development, and high innovation ability can facilitate the innovation compensation effect of environmental regulation.

Our study provides more support for investigating the economic impact of environmental regulation. Existing studies have touched upon air and water pollution [26], innovation [27], economic growth [28], and TFP [29]. Shao and Xiao argued that the previous GDP-oriented economic development model is difficult to sustain in China and that the quality of economic development is an important indicator of economic sustainability [30]. Borensztein and Ostry further argued that TFP can be used as an indicator to measure the quality of economic development [31]. Owing to the importance of green development of the marine economy, we examine the impact of environmental regulation on the GTFP of marine economy. Existing studies have discussed regional GTFP [32], industrial GTFP [33, 34]. However, few existing studies have explored the GTFP of the marine economy. We provide a useful supplement to the research concerning the economic impact of environmental regulation.

The results of this study reveal the temporal effect of environmental regulation on the GTFP of the marine economy. The short-term impact of environmental regulation is different from its long-term impact, which has been verified in developed countries [35]. In developing countries (e.g. China), Liang et al. found that the short-term impact of environmental regulation on regional GTFP is different from its long-term impact [36]. We find that environmental regulation can improve the GTFP of the marine economy in the long run rather than in the short run, and it contains specific policy implications and help managers gain insight into the relationship between environmental regulation and green development of marine economy. In brief, we provide empirical evidence for achieving a winwin situation between the development of the marine economy and the protection of marine environments through appropriate environmental policies.

Within a unified framework, we investigate the heterogeneous impact of environmental regulation under different economic development and technological levels on the GTFP of marine economy. First, according to the promotion tournament theory [24, 25], whether officials are promoted is positively correlated with regional economic growth, and strict environmental regulation may hurt GDP growth [37]. Using economic development level as the threshold variable, we find that a threshold effect exists in the impact of environmental regulation on the GTFP of the marine economy. Specifically, environmental regulation can significantly improve the GTFP of marine economics only when the economic development level exceeds its threshold. Second, according to the endogenous growth theory [38], existing knowledge stock can affect the innovation ability, specifically, the larger the existing knowledge stock is, the stronger the innovation ability is. The endogenous growth theory has been verified in many fields [39-41]. Using technological level as the threshold variable, we find that a threshold effect exists in the impact of environmental regulation on the GTFP of marine economy. Specifically, environmental regulation can significantly improve the GTFP of marine economy only when the technological level 
exceeds its threshold. The conclusions provide not only a theoretical foundation for how to develop marine economy in different regions, but also the Chinese experience for other developing countries to use as a model for attaining sustainable development of marine economy based on their actual conditions.

The remainder of the paper is organized as follows. Section 2 describes the data and presents the empirical strategy. The empirical results and discussions are presented in Section 3. Section 4 summarizes this study.

\section{Model Construction and Variable Selection}

\section{Model Construction}

\section{GTFP Measurement}

Four steps are needed to calculate marine green total factor productivity. The first is to choose an appropriate model which is the Malmquist-Luenberger SBM model in this paper. The second is to determine input indicators and output indicators. Input indicators in this paper include labor force and capital stock, while output indicators include the desirable and undesirable output. The third is to calculate GFTP using the MAXDEA software with Malmquist-Luenberger SBM model and panel data of China's marine economy. The fourth is to decompose GFTP into Tech and Effch with MalmquistLuenberger SBM mode for further research.

Following Long et al. [42], we calculate the GTFP of China's marine economy using the MalmquistLuenberger SBM model of undesirable output, and the Malmquist-Luenberger SBM index can be defined as follows.

$$
\begin{gathered}
M L_{t}^{t+1}=\left[\frac{1+\vec{D}_{0}^{t}\left(x^{t}, y^{t}, b^{t} ; y^{t},-b^{t}\right)}{1+\vec{D}_{0}^{t}\left(x^{t+1}, y^{t+1}, b^{t+1} ; y^{t+1},-b^{t+1}\right)}\right. \\
\left.\times \frac{1+\vec{D}_{0}^{t+1}\left(x^{t}, y^{t}, b^{t} ; y^{t},-b^{t}\right)}{1+\vec{D}_{0}^{t+1}\left(x^{t+1}, y^{t+1}, b^{t+1} ; y^{t+1},-b^{t+1}\right)}\right]^{1 / 2}
\end{gathered}
$$

...where $D_{0}^{t}\left(X^{t}, Y^{t}\right)$ represents the directional distance function of $\left(X^{t}, Y^{t}\right)$ in the $t$ period, $D_{0}^{t+1}\left(X^{t}, Y^{t}\right)$ represents the directional distance function of $\left(X^{t}, Y^{t}\right)$ in the $t+1$ period, $D_{0}^{t}\left(X^{t+1}, Y^{t+1}\right)$ represents the directional distance function of $\left(X^{t+1}, Y^{t+1}\right)$ in the $t$ period, and $D_{0}^{t+1}\left(X^{t+1}, Y^{t+1}\right)$ represents the directional distance function of $\left(X^{t+1}, Y^{t+1}\right)$ in the $t+1$ period, while $M L_{t}^{t+1}$ represents the total factor productivity. We select the resource dependence and environmental pollution as the undesirable output, therefore, the ML indexes with undesirable output is considered the green total factor productivity (GTFP).

Furthermore, the ML index can be decomposed into two sources, namely technological efficiency change (Effch) and technological progress (Tech). Effch denotes the efficiency change between two different time periods, and Tech denotes the technological changes between two different time periods.

$$
\begin{gathered}
\operatorname{GTFP}_{t}^{t+1}=\operatorname{Tech}_{t}^{t+1} \times E f f c h_{t}^{t+1} \\
\operatorname{Tech}_{t}^{t+1}=\left[\frac{1+\vec{D}_{0}^{t+1}\left(x^{t}, y^{t}, b^{t} ; y^{t},-b^{t}\right)}{1+\vec{D}_{0}^{t}\left(x^{t+1}, y^{t+1}, b^{t+1} ; y^{t+1},-b^{t+1}\right)}\right. \\
\left.\times \frac{1+\vec{D}_{0}^{t+1}\left(x^{t+1}, y^{t+1}, b^{t+1} ; y^{t+1},-b^{t+1}\right)}{1+\vec{D}_{0}^{t}\left(x^{t+1}, y^{t+1}, b^{t+1} ; y^{t+1},-b^{t+1}\right)}\right]^{1 / 2} \\
\operatorname{Effch}_{t}^{t+1}=\frac{1+\vec{D}_{0}^{t}\left(x^{t}, y^{t}, b^{t} ; y^{t},-b^{t}\right)}{1+\vec{D}_{0}^{t}\left(x^{t+1}, y^{t+1}, b^{t+1} ; y^{t+1},-b^{t+1}\right)}
\end{gathered}
$$

...where $\operatorname{GTFP}_{t}^{t+1}, \operatorname{Tech}_{t}^{t+1}$, Effch $_{t}^{t+1}$ represents the green total factor productivity, technical progress, and technical efficiency of the marine economy from period $t$ to period $t+1$, respectively. When GTFP (Tech, Effch) $>1$, it represents a growth in the GTFP (Tech, Effch), and when GTFP (Tech, Effch)<1, it represents a decline in the GTFP (Tech, Effch).

\section{Dynamic Panel Model}

To estimate the hysteresis of environmental regulation on the marine economy GTFP, we use the lagged environmental regulation as a main independent variable. In addition, there might exist endogeneity, which is that past environmental regulation may influence the current input, such as strengthening of environmental regulation may reduce the current input. The SYS-GMM could alleviate the potential endogeneity through test of second-order serial correlation and the Hansen test of over-identification $[43,44]$. The SYS-GMM specification is presented as follows.

$$
Y_{i, t}=\alpha_{0}+\alpha_{1} Y_{i, t-1}+\alpha_{2} E R_{i, t}+\alpha_{3} C V_{i, t}+\varepsilon_{i, t}
$$

...where $i$ represent province or city and $t$ represents year. $Y_{i, t}$ represents the green total factor productivity (GTFP), technological progress (Tech), and technological efficiency (Effch), respectively. $E R_{i, t}$ represents the environmental regulation from investment or cost perspective, $E R_{i, t-j}$ represents the environmental regulation with lag-j, and $\varepsilon_{\mathrm{i}, \mathrm{t}}$ represents the error term. $C V_{i, t}$ represents a vector of control variables. Our primary interest are the coefficient $\alpha_{2}$ and $\alpha_{3}$, because they capture the impact of the environmental regulation on GTFP.

\section{Threshold Model}

In order to examine the non-linear relationship between environmental regulation and GTFP, we employ the fixed-effect panel threshold model following the literature of Hansen [44], and Wang [45]. Taking one 
single-threshold model as an example, the specification is presented as follows.

$$
T F P_{i, t}=\alpha_{0}+\alpha_{1} E R_{i, t} \times I\left(q_{i . t} \leq \gamma\right)+\alpha_{2} E R_{i, t} \times I\left(q_{i, t}>\gamma\right)+\alpha_{3} C V_{i, t}+\varepsilon_{i, t}
$$

...where $I(\cdot)$ is the indicator function, $q_{i, t}$ represents the threshold variable which in our study is environmental regulation, economic development level and technological level, respectively, and $\gamma$ represents the threshold value that needs to be estimated. The value of the indicator function $I(\cdot)$ is 0 or 1 . If the expression of the indicator function holds, its value is equal to 1 , otherwise its value is 0 .

$E R$ represents the independent variables, referring to the environmental regulation. By comparing the value of the threshold variable and threshold value, our observations can be split into two regimes, and we analyze the two differing mechanisms through the regression coefficients $\alpha_{1}$ and $\alpha_{2}$. CV $V_{i, t}$ represents control variables, and $\varepsilon_{i, t}$ represents the error term.

\section{Data Source}

We collect data from of 11 provinces and cities along the coast of China from 2001 to 2016 to estimate the GTFP, and evaluate how it is affected by the environmental regulation. These 11 provinces and cities are Liaoning, Hebei, Tianjin (city), Shandong, Jiangsu, Shanghai (city), Zhejiang, Fujian, Guangdong, Hainan, and Guangxi. The data mainly come from China Environmental Statistics Yearbook, China Ocean Yearbook, China Statistical Yearbook in the years 20022017, and Marketization index of China's province: Neri report 2018.

\section{Indicator Selection}

\section{Input and Output Indicators}

In order to evaluate the marine economy GTFP, input includes labor force and capital stock, while output dissatisfied desirable and undesirable, and Table 1 shows the basic data description of input and output indicators. We calculate the labor force by the number of sea related employment, calculate the capital stock through perpetual inventory. Desirable output includes the marine economic output of coastal provinces (cities), and undesirable output includes resource and environment loss across different coastal provinces (cities) of China.

The prior researches usually estimated the capital stock through perpetual inventory approach. However, the data which is required to calculate the capital stock for marine economy of China is difficult to obtain. Therefore, we estimate the marine economic capital stock following the idea of Sun and Song [46]. The specific steps are as follows. Choosing 2000 as the baseline year, the capital stock of the coastal province is estimated through perpetual inventory method firstly. Then, we get the marine economic capital stock by the following formula.

$$
K_{t}^{\text {sea }}=K_{t} \times \frac{G O P_{t}}{G D P_{t}}
$$

...where $K_{t}^{\text {sea }}$ denotes the marine economic capital stock, $K_{t}$ denotes the total economic capital stock, and $\frac{G O P_{t}}{G D P}$ denotes the proportion of marine economy in GDP. ${ }^{G D P_{t}}$

The undesirable output includes a few bad indicators. To overcome deviation from the singleness of indicator, undesirable output includes a few detrimental activities (e.g. resource consumption and environmental pollution) that hurt the marine ecology. The sample only covers China's 11 provinces (cities), thus, the number of decision-making units is small. To prevent an overestimation of efficiency, it is necessary to reduce the number of input and output indicators as much as possible. Therefore, the indicators of the detrimental activities are integrated into one indicator using the entropy method. The general steps of the entropy method are as follows. The first is to set up an original data matrix including all the indicators. The second is to process the data dimensionless to make it comparable. The third is to calculate the specific gravity matrix of the index system and the entropy value of each indicator. The fourth is to calculate the coefficient of difference and then determine the weight of each indicator. The last is to calculate the comprehensive score level of each sample. Such indicators of detrimental activities mainly include marine fishing yield which indicates the dependence on fishery resources, and emissions of industry waste water, industrial solid waste, industrial sulphur dioxide, and industrial fumes which indicates

Table 1. Description of input and output indicators.

\begin{tabular}{|c|c|c|c|c|c|c|c|}
\hline Type & Name & Unit & Obs. & Mean & S.D. & Min & Max \\
\hline \multirow{2}{*}{ Input } & Labor & 10 thousand Person & 176 & 298.1 & 206.0 & 76.5 & 860.3 \\
\cline { 2 - 9 } & Capital & 100 million Yuan & 176 & 1926 & 1649 & 61.38 & 9625 \\
\hline Desirable & GOP & 100 million Yuan & 176 & 3641 & 2969 & 147.2 & 14443 \\
\hline Undesirable & Bad output & - & 176 & 0.314 & 0.170 & 0.055 & 0.644 \\
\hline
\end{tabular}

Notes: Obs. denotes observation. S.D. denotes standard deviation. Yuan means China's currency Yuan Renminbi. 
the marine pollution. The data on marine fishery yield comes from the China Ocean Yearbook.

No data on environmental pollution of the marine economy is directly available. Following the method of Sun and Song [46], marine environmental pollution is measured in terms of related indicators (e.g. marine industrial wastewater emissions, marine industrial solid waste emissions, marine industrial sulphur dioxide emissions, and marine industrial fumes emissions) of provincial-level coastal regions, which were converted from related indicators (e.g. province-wide industrial waste water, industrial solid waste emissions, industrial sulphur dioxide emissions, and industrial fumes emissions).

\section{Explained Variables and Control Variables}

The main explanatory variable of our study is environmental regulation.

Following the idea of Lanoie et al. [47], environmental regulation indices is constructed from the perspectives of investment and cost. The investmentbased environmental regulation index can effectively reflect governments' efforts in environmental protection, thus helping governments review the effectiveness of environmental regulation. Here, investment in environmental harnessing refers to governments' direct investment in environmental harnessing and serves to alleviate environmental pollution quickly and effectively, improve environmental quality, and provide some guidance for green production. From the perspective of cost, pollution discharge fees levied on enterprises can increase their environmental consciousness and encourage them to make technological innovation and improve corporate management, thus exerting a certain innovation compensation effect. The environmental regulation index is calculated using the following equation.

$$
E R_{i, t}=\frac{E V_{i, t} / G D P_{i, t}}{E V_{t} / G D P_{t}}
$$

...where $E V_{i, t}$ denotes the investment in environmental pollution control or pollution discharge fees with respect to the provincial-level region $i$ in $t$ year, $G D P_{i, t}$ denotes the GDP of the provincial-level region $i$ in $t$ year, $E V_{t}$ denotes the national investment in environmental pollution control or pollution discharge fees, and $G D P_{t}$ denotes the national GDP in $t$ year. If $E R_{i, t}$ is greater than 1 , the intensity of environmental regulation is high in the provincial-level region $i$, if $E R_{i, t}$ is less than 1, the intensity of environmental regulation is low in the provincial-level region $i$.

Threshold variable

To reduce or completely offset the addition cost incurred by environmental regulation, enterprises must actively engage in innovations. Existing knowledge stock can affect innovation ability. For the marine economy, the higher an innovator's technological level is, the stronger their innovation ability is, and the more adaptable they are to environmental regulation. In the face of increasing environmental regulation, the GTFP of marine economy is easier to be promoted.

There is GDP competition between local governments [24, 25], and the intensity of environmental regulation affects the local GDP. Therefore, when formulating and implementing environmental policies, local governments fully consider their impact on the local economy. If the local economic development level is low, local governments may formulate loose environmental policies to protect local economic development and improve economic data. In this case, environmental regulation has a slight impact on the GTFP of marine economy. If the local economic development level is high, local governments attach more importance to green development and formulate and implement environmental policies more strictly. In this case, environmental regulation has a significant impact on the GTFP of marine economy.

Based on the threshold model above, environmental regulation, technological level, and local economic development level are used as threshold variables. Specifically, technological level is measured in terms of the total number of marine economy research projects [48], and local economic development level is measured in terms of per-capita GDP.

We also control for several variables of interest for our investigation that have been documented important for GTFP.

The marketization level (Market). The improvement of the marketization level can optimize the allocation of resources, improve the relationship between the government and the market, and then affect GTFP. We use the marketization index of Wang et al. as the indicator of the marketization level [49].

Innovation investment $(R D)$. Innovation activities are inseparable from financial support, we use the proportion of R\&D investment in GDP as the indicator of innovation investment.

Labor quality (Labor). Labor is the most basic element in economic activities, and the level of labor quality can affect production efficiency and innovation capabilities. We measure the labor quality by the average years of education of the labor force, and it is presented as follows.

$$
\text { Labor }=X_{1} \times 6+X_{2} \times 9+X_{3} \times 12+X_{4} \times 16
$$

...where $X 1, X 2, X 3$, and $X 4$ represents the proportions of residents who have received primary school, junior high school, high school, college education and above among the population aged 6 and over, respectively. We make the assignment of 6-9-12-16 according to the current state of education in China. The length of primary school, junior high school, high school and college is 6 years, 3 years, 3 years 
Table 2. Descriptive statistical analysis.

\begin{tabular}{|c|c|c|c|c|c|}
\hline Variables & Obs. & Mean & S.D. & Min & Max \\
\hline GTFP & 176 & 1.012 & 0.109 & 0.697 & 1.366 \\
\hline Tech & 176 & 0.971 & 0.086 & 0.754 & 1.200 \\
\hline$E f f c h$ & 176 & 1.042 & 0.066 & 0.903 & 1.319 \\
\hline$E I$ & 176 & 0.986 & 0.643 & 0.214 & 10.156 \\
\hline$P D F$ & 176 & 1.107 & 0.793 & 0.051 & 6.984 \\
\hline$P G D P$ (Unit:10000 Yuan) & 176 & 2.695 & 1.435 & 0.466 & 6.701 \\
\hline$T L$ (Unit:1000) & 176 & 7.066 & 6.452 & 0.097 & 26.640 \\
\hline SIS & 176 & 0.478 & 0.074 & 0.313 & 0.639 \\
\hline RD (Unit: \%) & 176 & 1.622 & 0.852 & 0.199 & 3.726 \\
\hline Labor & 176 & 8.949 & 0.882 & 8.013 & 11.310 \\
\hline Urban & 176 & 0.593 & 0.149 & 0.350 & 0.900 \\
\hline Market & 176 & 7.568 & 1.574 & 4.230 & 10.920 \\
\hline
\end{tabular}

Notes: $E I, P D F$ denotes the environmental regulation form investment and cost perspective, respectively. $T L$ represents the total number of marine economy research projects. Obs. denotes observation. S.D. denotes standard deviation. Yuan means China's currency Yuan Renminbi.

and 4 years respectively. So we use the 6-9-12-16 years of education to represent the four levels of education.

Marine industrial structure (SIS). Factor inputs and pollutant emissions of different industries are different, so the industrial structure will affect GTFP. We use the proportion of the output value of the tertiary industry of marine economy in the total output of the marine economy as the indicator of marine industrial structure.

The level of urbanization (Urban). Urban areas have a strong agglomeration effect on production factors, which is able to affect the productivity. We use the proportion of permanent population in the total population as the indicator of urbanization level.

Table 2 shows the basic statistical characteristics of the key variables.

\section{Empirical Results}

\section{Results of Marine Economy GTFP}

The GTFP of marine economy in 11 coastal provinces (cities) of China in the years 2001-2016 is measured with the aid of the MAXDEA software. Table 3 and Fig. 1 present the results.

According to Table 3, taking resources and environmental losses as undesired outputs, the calculated of average GTFP value is greater than the average TFP without considering resource and environmental losses. According to Fig. 1, GTFP, Tech and Effch of marine economy fluctuate during the inspection period, but the overall trend is upward.
When the source and environmental losses are not considered, there will be a certain decrease in TFP during the inspection period, with an average annual decrease of $0.07 \%$. Among them, the TFP of Shanghai city, Guangdong province, Jiangsu province, Shandong province, and Zhejiang province increase, while the remaining provinces decline. The TFP of Shanghai city, Guangdong province, and Jiangsu province increase significantly, with average annual growth rates of $5.52 \%, 4.98 \%$ and $3.64 \%$, respectively. The TFP of Hainan province, Guangxi province, and Fujian province fall sharply, with an average annual decrease of $7.03 \%, 5.74 \%$ and $2.76 \%$, respectively. When the undesired output is considered, the average annual growth rate of GTFP during the inspection period is $1.31 \%$. In addition to the growth of GTFP in Shanghai city, Guangdong province, Jiangsu province, Shandong province and Zhejiang province, the GTFP in Tianjin city also increase, and the remaining provinces have experienced a decline. Guangdong province, Shanghai city, and Jiangsu province, which experienced larger GTFP gains, have average annual gains of $7.96 \%$, $6.95 \%$, and $5.78 \%$, respectively, while Guangxi province, Hainan province, and Fujian province have larger annual decreases of $5.65 \%, 5.46 \%$, and $2.51 \%$, respectively.

From the perspective of the decomposition of productivity, regardless of whether undesirable output is considered, the value of technical efficiency in most provinces is greater than the value of technological progress, which shows that technical efficiency is still an important internal factor driving the productivity of Chinese marine economy. 
Table 3. Marine economy GTFP and its decomposition.

\begin{tabular}{|c|c|c|c|c|c|c|c|c|}
\hline Province & TFP & TC & TE & Rank & GTFP & GTC & GTE & Rank \\
\hline Guangdong & 1.0498 & 0.9917 & 1.0574 & 2 & 1.0796 & 1.0340 & 1.0445 & 1 \\
\hline Shanghai & 1.0552 & 1.0207 & 1.0329 & 1 & 1.0695 & 1.0210 & 1.0695 & 2 \\
\hline Jiangsu & 1.0364 & 1.0036 & 1.0453 & 3 & 1.0578 & 1.0111 & 1.0478 & 3 \\
\hline Shandong & 1.0308 & 0.9836 & 1.0496 & 4 & 1.0570 & 0.9997 & 1.0554 & 4 \\
\hline Zhejiang & 1.0137 & 0.9875 & 1.0324 & 5 & 1.0454 & 0.9966 & 1.0469 & 5 \\
\hline Tianjin & 0.9973 & 0.9524 & 1.0358 & 6 & 1.0044 & 0.9648 & 1.0420 & 6 \\
\hline Hebei & 0.9853 & 0.9365 & 1.0367 & 8 & 0.9896 & 0.9543 & 1.0403 & 7 \\
\hline Liaoning & 0.9879 & 0.9497 & 1.0342 & 7 & 0.9890 & 0.9540 & 1.0375 & 8 \\
\hline Fujian & 0.9724 & 0.9926 & 0.9796 & 9 & 0.9749 & 0.9523 & 1.0253 & 9 \\
\hline Hainan & 0.9297 & 1.0123 & 0.8991 & 11 & 0.9454 & 0.9179 & 1.0298 & 10 \\
\hline Guangxi & 0.9426 & 0.9052 & 1.0149 & 10 & 0.9435 & 0.9017 & 1.0225 & 11 \\
\hline Mean & 0.9993 & 0.9754 & 1.0189 & - & 1.0131 & 0.9726 & 1.0419 & - \\
\hline
\end{tabular}

Notes: TFP is the result wihout considering undesirable output, and GTFP is the result considering undesirable output.

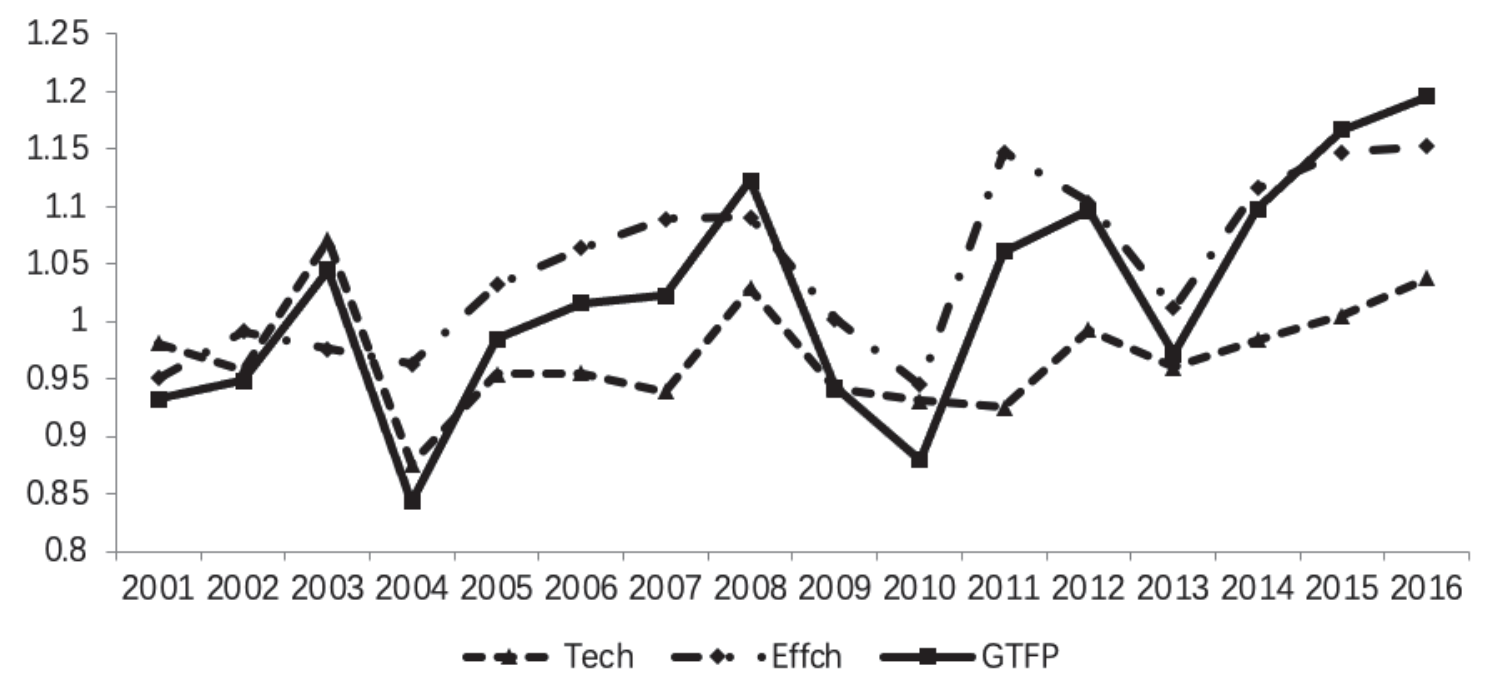

Fig. 1. The trend of GTFP, Tech and Effch of marine economy from 2001-2016.

Result of the Temporal Effect of Environmental Regulation on the GTFP

We use the SYS-GMM to analyze the temporal effect of environmental regulation on the GTFP of the marine economy in China. The estimation results are recorded in Table 4. The $p$ values of AR(1) test, AR(2) test, and Hansen test show that the SYS-GMM estimators are valid.

As shown in Table 4, the coefficients for the current period $E R$ are all negative in the six models, but are only significant in model 4 and model 5 . It suggests that the current period $E R$ from the investment perspective has an insignificant negative effect on GTFP, but has a significant negative effect from the cost perspective. Meanwhile, the coefficients for the lagged $E R$ are all positive in the six models which suggest the lagged $E R$ will stimulate innovation compensation effect and increase the GTFP of marine economy. By comparing the size of the coefficients, we can see that the L2.ER has the greatest impact on GTFP both from the investment perspective and from the cost perspective.

As shown in Table 5, the coefficients for the current period $E R$ from investment and cost perspective are all negative but insignificant. Meanwhile, the coefficients for the lagged $E R$ are all positive and statistically significant, which suggests the impact of lagged $E R$ on GTFP will become positive and significant. Besides, the L1.ER has the greatest impact on Effch both from the investment perspective and from the cost perspective.

As shown in Table 6, the coefficients for the current period $E R$ from investment and cost perspective are all 
Table 4. Temporal effect of environmental regulation on the GTFP.

\begin{tabular}{|c|c|c|c|c|c|c|}
\hline \multirow{2}{*}{ Variable } & \multicolumn{3}{|c|}{ Investment perspective } & \multicolumn{3}{|c|}{ Cost perspective } \\
\hline & Model $1(\mathrm{j}=1)$ & Model $2(j=2)$ & Model $3(j=3)$ & Model $4(\mathrm{j}=1)$ & Model $5(j=2)$ & Model $6(j=3)$ \\
\hline L.GTFP & $\begin{array}{c}0.4345^{* * *} \\
(2.91)\end{array}$ & $\begin{array}{c}0.3905^{* * *} \\
(2.79)\end{array}$ & $\begin{array}{l}0.6391 \\
(1.15)\end{array}$ & $\begin{array}{c}0.8620 * * * \\
(3.06)\end{array}$ & $\begin{array}{c}0.5743 * * \\
(1.98)\end{array}$ & $\begin{array}{c}0.7770 \\
(1.01)\end{array}$ \\
\hline$E R$ & $\begin{array}{c}-0.0451 \\
(-1.40)\end{array}$ & $\begin{array}{c}-0.0106 \\
(-1.23)\end{array}$ & $\begin{array}{c}-0.0392 \\
(-1.26)\end{array}$ & $\begin{array}{c}-0.0256^{* * * *} \\
(-2.75)\end{array}$ & $\begin{array}{c}-0.0371 * * * \\
(-3.81)\end{array}$ & $\begin{array}{c}-0.0244 \\
(-0.87)\end{array}$ \\
\hline$L j . E R$ & $\begin{array}{c}0.0812 * * * \\
(3.91)\end{array}$ & $\begin{array}{c}0.0426 * * * * \\
\quad(4.23)\end{array}$ & $\begin{array}{l}0.0101 \\
(0.93)\end{array}$ & $\begin{array}{c}0.0260 * * * \\
(2.86)\end{array}$ & $\begin{array}{c}0.0544 * * * \\
(3.24)\end{array}$ & $\begin{array}{c}0.0229 * \\
(1.82)\end{array}$ \\
\hline SIS & $\begin{array}{c}0.0477 * * * \\
(2.84)\end{array}$ & $\begin{array}{c}0.2263 * * \\
(2.04)\end{array}$ & $\begin{array}{l}0.0671 \\
(1.18)\end{array}$ & $\begin{array}{c}0.7463 * * * \\
\quad(3.26)\end{array}$ & $\begin{array}{c}0.0188 * * \\
(2.02)\end{array}$ & $\begin{array}{c}0.3761 \\
(0.87)\end{array}$ \\
\hline$R D$ & $\begin{array}{c}0.2074 * * * \\
(2.96)\end{array}$ & $\begin{array}{c}0.2228 * * * \\
(3.45)\end{array}$ & $\begin{array}{l}0.1140 \\
(1.13)\end{array}$ & $\begin{array}{c}0.0895 * * * \\
(3.04)\end{array}$ & $\begin{array}{l}0.3704 \\
(0.96)\end{array}$ & $\begin{array}{c}0.0773 \\
(0.84)\end{array}$ \\
\hline Labor & $\begin{array}{c}0.2419 * * * \\
(2.83)\end{array}$ & $\begin{array}{c}0.1048^{* *} \\
(2.13)\end{array}$ & $\begin{array}{l}0.5455 \\
(1.25)\end{array}$ & $\begin{array}{c}0.3273 * * \\
(2.01)\end{array}$ & $\begin{array}{c}0.5685^{* *} \\
(2.23)\end{array}$ & $\begin{array}{c}0.7170^{*} \\
(1.82)\end{array}$ \\
\hline Urban & $\begin{array}{c}0.6219 * * * \\
(4.82)\end{array}$ & $\begin{array}{c}1.3119^{* * *} \\
(3.64)\end{array}$ & $\begin{array}{c}1.1529 * * \\
(2.14)\end{array}$ & $\begin{array}{c}0.7506^{* * *} \\
\quad(3.64)\end{array}$ & $\begin{array}{c}0.1030 * * \\
(1.96)\end{array}$ & $\begin{array}{c}0.2793 \\
(1.02)\end{array}$ \\
\hline Market & $\begin{array}{c}0.0062 * * * \\
(4.27)\end{array}$ & $\begin{array}{c}0.0411^{*} \\
(1.81)\end{array}$ & $\begin{array}{c}0.0084^{*} \\
(1.82)\end{array}$ & $\begin{array}{c}0.0041 * * * \\
(3.40)\end{array}$ & $\begin{array}{c}0.0546 * * \\
(2.15)\end{array}$ & $\begin{array}{l}0.0023 \\
(1.26)\end{array}$ \\
\hline Consant & $\begin{array}{c}-2.3801 * * * \\
(-3.59)\end{array}$ & $\begin{array}{c}-1.9185 \\
(-0.84)\end{array}$ & $\begin{array}{c}-5.4923^{*} \\
(-1.82)\end{array}$ & $\begin{array}{c}-3.8104 * * \\
(-2.08)\end{array}$ & $\begin{array}{c}-5.8064 \\
(-1.16)\end{array}$ & $\begin{array}{c}-6.7024 \\
(-1.23)\end{array}$ \\
\hline Hansen ( $p$-value) & 0.195 & 0.234 & 0.216 & 0.362 & 0.391 & 0.357 \\
\hline AR (1) ( $p$-value) & 0.007 & 0.003 & 0.004 & 0.005 & 0.014 & 0.003 \\
\hline $\operatorname{AR}(2)$ ( $p$-value) & 0.266 & 0.352 & 0.239 & 0.316 & 0.387 & 0.293 \\
\hline
\end{tabular}

Notes: We list the results of the current period and the three lagging periods considering the validity of the regression results. Investment perspective means the main explain variable is $E I$, Cost perspective means the main explain variable is $P D F$. ***, ** and $*$ denote significance at the $1 \%, 5 \%$ and $10 \%$ levels, respectively. Figures in parenthesis are $t$-value.

negative. Meanwhile, the coefficients of lagged $E R$ are all positive, the coefficients of L1.ER and L2.ER from investment perspective are positive and statistically significant, the coefficients of L1.ER and L2.ER from cost perspective are positive and statistically significant, which suggests the impact of lagged ER on GTFP will become positive and significant. Besides, the L2.ER has the greatest impact on Tech both from the investment perspective and from the cost perspective.

\section{Result of the Threshold Effect of ER on GTFP}

\section{Baseline Results}

Following the idea of Hansen [48], we use the bootstrapping method to calculate the value of $F$-statistics and obtain the $p$-value. According to the results, we examine whether the threshold effect exists, and evaluate the number of thresholds. According to the previous analysis, we use environmental regulation, the economic development level, and technological level, as the threshold variables, respectively.

Table 7 presents results of the single, and double threshold effect tests. From the investment perspective: (1) For EI, only the $p$-value for a single-threshold model is significant at 0.0300 , while the test for a double-threshold is insignificant at 0.2900 . Therefore, the empirical result implies only one threshold with environmental regulation from investment perspective as the threshold variable. (2) For $P G D P$, only the $p$-value for a single-threshold model is significant at 0.0400, while the test for a double-threshold is insignificant at 0.5700 . Therefore, the empirical result implies only one threshold with economic development level as the threshold variable. (3) For $T L$, only the $p$-value for a single-threshold model is significant at 0.0000 , while the test for a double-threshold is insignificant at 0.8700 . Therefore, the empirical result implies only one threshold with technological level as the threshold variable.

From the cost perspective, we also find there is only one threshold with environmental regulation, economic development level, technological level as the threshold variable, respectively.

Table 8 further reports the threshold estimators and confidence intervals. From the investment perspective (column 1 3): (1) For EI, Column 1 3 and row 2 3 presents the estimated values of one threshold, the threshold estimator is 0.4721 with $E I$ as the threshold variable. Thus, the observations of $E I$ can be split into two regimes, namely, weak EI regime $(E I \leq 0.4721)$, and strong EI regime $(E I>0.4721)$. (2) For $P G D P$, Column 
Table 5. Temporal effect of environmental regulation on the technological efficiency.

\begin{tabular}{|c|c|c|c|c|c|c|}
\hline \multirow{2}{*}{ Variable } & \multicolumn{3}{|c|}{ Investment perspective } & \multicolumn{3}{|c|}{ Cost perspective } \\
\hline & Model $1(\mathrm{j}=1)$ & Model $2(\mathrm{j}=2)$ & Model $3(j=3)$ & Model $4(j=1)$ & Model $5(j=2)$ & Model $6(j=3)$ \\
\hline L.Effch & $\begin{array}{c}0.1279^{* * *} \\
(3.67)\end{array}$ & $\begin{array}{c}0.5579^{*} \\
(1.84)\end{array}$ & $\begin{array}{l}0.2716 \\
(1.05)\end{array}$ & $\begin{array}{c}0.2235^{* * *} \\
(3.26)\end{array}$ & $\begin{array}{l}0.0638 \\
(1.15)\end{array}$ & $\begin{array}{c}0.2749 \\
(0.89)\end{array}$ \\
\hline$E R$ & $\begin{array}{c}0.0221 \\
(1.34)\end{array}$ & $\begin{array}{l}0.0547 \\
(0.94)\end{array}$ & $\begin{array}{l}0.0856 \\
(1.03)\end{array}$ & $\begin{array}{l}0.0175 \\
(1.45)\end{array}$ & $\begin{array}{c}0.1022 \\
(0.98)\end{array}$ & $\begin{array}{l}0.0481 \\
(1.25)\end{array}$ \\
\hline$L j . E R$ & $\begin{array}{c}0.0633^{*} \\
(1.81)\end{array}$ & $\begin{array}{c}0.0493 * * * \\
(3.65)\end{array}$ & $\begin{array}{c}0.015^{* *} \\
(2.01)\end{array}$ & $\begin{array}{c}0.2280^{* * *} \\
(2.89)\end{array}$ & $\begin{array}{c}0.0126^{* * *} \\
(3.26)\end{array}$ & $\begin{array}{c}0.0157 * * * \\
(3.14)\end{array}$ \\
\hline$S I S$ & $\begin{array}{c}0.1036^{* * *} \\
(3.12)\end{array}$ & $\begin{array}{c}0.0206 * * * \\
(2.89)\end{array}$ & $\begin{array}{c}0.1843 * * \\
(2.15)\end{array}$ & $\begin{array}{c}0.3661 * * * \\
(3.68)\end{array}$ & $\begin{array}{c}0.0503^{*} \\
(1.82)\end{array}$ & $\begin{array}{c}0.2371^{*} \\
(1.83)\end{array}$ \\
\hline$R D$ & $\begin{array}{c}0.2648 * * * \\
\quad(2.23)\end{array}$ & $\begin{array}{c}0.9770 * \\
(1.81)\end{array}$ & $\begin{array}{c}0.5881 * \\
(1.86)\end{array}$ & $\begin{array}{c}0.4648 * * * \\
(3.65)\end{array}$ & $\begin{array}{c}0.4727 * \\
(1.83)\end{array}$ & $\begin{array}{c}0.5336 \\
(1.22)\end{array}$ \\
\hline Labor & $\begin{array}{c}0.2202 * * * \\
(2.82)\end{array}$ & $\begin{array}{c}0.2956^{* * *} \\
(3.15)\end{array}$ & $\begin{array}{c}0.1022 \\
(1.26)\end{array}$ & $\begin{array}{c}0.4273 * * * \\
(3.69)\end{array}$ & $\begin{array}{c}0.8462 * * * \\
(2.89)\end{array}$ & $\begin{array}{l}1.0133 \\
(1.15)\end{array}$ \\
\hline Urban & $\begin{array}{c}1.2983^{* *} \\
(2.10)\end{array}$ & $\begin{array}{c}1.3318^{*} \\
(1.83)\end{array}$ & $\begin{array}{c}1.3950^{*} \\
(1.82)\end{array}$ & $\begin{array}{c}0.4278^{* * *} \\
(4.03)\end{array}$ & $\begin{array}{c}1.2267^{*} \\
(1.87)\end{array}$ & $\begin{array}{c}1.6914 * \\
(1.85)\end{array}$ \\
\hline Market & $\begin{array}{c}0.0133^{* * *} \\
(2.93)\end{array}$ & $\begin{array}{c}0.1824^{*} \\
(1.82)\end{array}$ & $\begin{array}{l}0.0486 \\
(0.84)\end{array}$ & $\begin{array}{c}0.0291^{* *} \\
(2.14)\end{array}$ & $\begin{array}{c}0.0472 \\
(0.94)\end{array}$ & $\begin{array}{l}0.0803 \\
(1.15)\end{array}$ \\
\hline Consant & $\begin{array}{c}-2.5314 * * * \\
(-3.23)\end{array}$ & $\begin{array}{c}-6.0558 \\
(-0.96) \\
\end{array}$ & $\begin{array}{c}-2.3816 \\
(-1.03) \\
\end{array}$ & $\begin{array}{c}-4.6717 * * \\
(-2.08)\end{array}$ & $\begin{array}{c}-8.5976 \\
(-1.05) \\
\end{array}$ & $\begin{array}{c}-11.2655 \\
(-1.25) \\
\end{array}$ \\
\hline Hansen ( $p$-value) & 0.168 & 0.322 & 0.256 & 0.302 & 0.318 & 0.296 \\
\hline $\operatorname{AR}(1)(p$-value $)$ & 0.002 & 0.001 & 0.004 & 0.016 & 0.001 & 0.001 \\
\hline AR (2) ( $p$-value) & 0.394 & 0.267 & 0.193 & 0.547 & 0.347 & 0.263 \\
\hline
\end{tabular}

Notes: We list the results of the current period and the three lagging periods considering the validity of the regression results. Investment perspective means the main explain variable is $E I$, and Cost perspective means the main explain variable is $P D F$. ***,** and $*$ denote significance at the $1 \%, 5 \%$ and $10 \%$ levels, respectively. Figures in parenthesis are $t$-value.

$1 \sim 3$ and row 4 5 presents the estimated values of one thresholds, the threshold estimator is 3.5743 with $P G D P$ as the threshold variable. Thus, the observations of $P G D P$ can be split into two regimes, namely, low PGDP regime $(P G D P \leq 3.5743)$, and high PGDP regime (PGDP>3.5743). (3) For $T L$, Column $1 \sim 3$ and row 6 7 presents the estimated values of one thresholds, the threshold estimator is 15.1900 with $T L$ as the threshold variable. Thus, the observations of $T L$ can be split into two regimes, namely, lower TL regime $(T L \leq 15.1900)$, and higher $T L$ regime $(T L>15.1900)$.

From the cost perspective (column 4 6), the same method is used to split observations of $P D F, P G D P$ and $T L$ into two regimes, respectively.

\section{Estimation Results of the Threshold Model}

Column $2 \sim 3$ in Table 9 reports the estimation results of a single threshold model with $E I$ as threshold variable. It confirms a non-linear relationship between $E I$ and GTFP with one turning point. When the value of $E I$ is less than 0.4721, that is, under the weak EI regime, the coefficient of $E I$ is 0.0305 but insignificant. When the value of $E I$ crosses the threshold, i.e. in the strong EI regime $(E I>0.4721)$, however, the coefficient of $E I$ equals to 0.1120 and statistically significant at the $1 \%$ level. This suggests that environmental regulation has no significant impact on GTFP if it is below the $E I$ threshold, while the impact on GTFP is positive if it is above the $E I$ threshold.

Column 4 5 in Table 9 reports the estimation results of a single threshold model with $P D F$ as threshold variable. It also confirms a non-linear relationship between $P D F$ and GTFP with one turning point. When the value of $P D F$ is less than 0.5087 , that is, under the weak PDF regime, the coefficient of $P D F$ is -0.0578 and statistically significant at the $5 \%$ level. When the value of $P D F$ crosses the threshold, i.e. in the strong PDF regime $(P D F>0.5087)$, however, the coefficient of $P D F$ equals to 0.0192 and statistically significant at the $1 \%$ level. This suggests that environmental regulation has a negative impact on GTFP if it is below the PDF threshold, while the impact on GTFP is positive if it is above the $P D F$ threshold.

Table 10 reports the estimation results of a single threshold model with $P G D P$ as the threshold variable. From the perspective of investment and cost, it confirms a non-linear relationship between environmental regulation and the GTFP with one turning point, respectively. Column 2 3 reports the estimation results from investment perspective. When the value of $P G D P$ is less than 3.5743 , that is, under 
Table 6. Temporal effect of environmental regulation on the technological progress.

\begin{tabular}{|c|c|c|c|c|c|c|}
\hline \multirow{2}{*}{ Variable } & \multicolumn{3}{|c|}{ Investment perspective } & \multicolumn{3}{|c|}{ Cost perspective } \\
\hline & Model $1(\mathrm{j}=1)$ & Model $2(j=2)$ & Model $3(j=3)$ & Model $4(\mathrm{j}=1)$ & Model $5(\mathrm{j}=2)$ & Model $6(j=3)$ \\
\hline L.Tech & $\begin{array}{c}0.1239^{* * *} \\
(2.84)\end{array}$ & $\begin{array}{c}0.1043^{* *} \\
(2.15)\end{array}$ & $\begin{array}{c}-0.0315 \\
(-0.95)\end{array}$ & $\begin{array}{c}0.0306^{* * *} \\
(4.03)\end{array}$ & $\begin{array}{c}0.0766^{* *} \\
(2.12)\end{array}$ & $\begin{array}{l}0.0724 \\
(1.35)\end{array}$ \\
\hline$E R$ & $\begin{array}{c}-0.0245^{* *} \\
(-2.14)\end{array}$ & $\begin{array}{l}0.0483 \\
(-1.36)\end{array}$ & $\begin{array}{c}-0.0119 \\
(-0.86)\end{array}$ & $\begin{array}{c}-0.2043 * * * \\
(-3.65)\end{array}$ & $\begin{array}{c}-0.1105^{* * * *} \\
(-3.65)\end{array}$ & $\begin{array}{c}-0.0929 \\
(-1.23)\end{array}$ \\
\hline$L j . E R$ & $\begin{array}{c}0.0209^{* * *} \\
\quad(3.20)\end{array}$ & $\begin{array}{c}0.032 * * * \\
(3.15)\end{array}$ & $\begin{array}{l}0.0176 \\
(1.23)\end{array}$ & $\begin{array}{c}0.2114 * * * \\
(3.65)\end{array}$ & $\begin{array}{c}0.2150^{* *} \\
(2.65)\end{array}$ & $\begin{array}{c}0.1033 \\
(0.97)\end{array}$ \\
\hline$S I S$ & $\begin{array}{c}0.1762 * * * \\
\quad(3.24)\end{array}$ & $\begin{array}{c}0.0927^{*} \\
(1.81)\end{array}$ & $\begin{array}{c}0.1381 * \\
(1.84)\end{array}$ & $\begin{array}{c}0.0668 * * * \\
(2.89)\end{array}$ & $\begin{array}{c}0.0349 * \\
(1.86)\end{array}$ & $\begin{array}{c}0.1026 \\
(0.63)\end{array}$ \\
\hline$R D$ & $\begin{array}{c}0.3097 * * \\
(2.06)\end{array}$ & $\begin{array}{c}0.2814 \\
(1.01)\end{array}$ & $\begin{array}{c}0.2659 \\
(1.42)\end{array}$ & $\begin{array}{c}0.8020^{*} \\
(1.82)\end{array}$ & $\begin{array}{c}0.4091 \\
(0.78)\end{array}$ & $\begin{array}{l}0.5023 \\
(1.24)\end{array}$ \\
\hline Labor & $\begin{array}{c}0.2232 * * \\
(2.14)\end{array}$ & $\begin{array}{c}0.1871 \\
(0.96)\end{array}$ & $\begin{array}{c}0.1971 \\
(1.32)\end{array}$ & $\begin{array}{c}0.2405^{* *} \\
(2.25)\end{array}$ & $\begin{array}{c}0.4461^{*} \\
(1.83)\end{array}$ & $\begin{array}{c}0.1943 \\
(0.45)\end{array}$ \\
\hline Urban & $\begin{array}{c}1.5018^{* * * *} \\
(3.69)\end{array}$ & $\begin{array}{c}1.8355^{*} \\
(1.81)\end{array}$ & $\begin{array}{l}2.0414 \\
(1.25)\end{array}$ & $\begin{array}{c}0.6404^{* * *} \\
(3.53)\end{array}$ & $\begin{array}{c}0.8784^{* * *} \\
(3.49)\end{array}$ & $\begin{array}{c}0.3162 * * \\
(2.16)\end{array}$ \\
\hline Market & $\begin{array}{c}0.0151^{* *} \\
(2.02)\end{array}$ & $\begin{array}{c}0.1410 \\
(1.35)\end{array}$ & $\begin{array}{c}0.1408 \\
(0.98)\end{array}$ & $\begin{array}{c}0.0349^{* * *} \\
(4.16)\end{array}$ & $\begin{array}{c}0.1140^{* * *} \\
(3.65)\end{array}$ & $\begin{array}{c}0.1328 \\
(1.02)\end{array}$ \\
\hline Consant & $\begin{array}{c}-2.6101^{* *} \\
(-1.97)\end{array}$ & $\begin{array}{c}-3.3498^{* *} \\
(-2.04)\end{array}$ & $\begin{array}{c}-3.4886 \\
(-0.91)\end{array}$ & $\begin{array}{c}-3.1387 * * * \\
(-5.23)\end{array}$ & $\begin{array}{c}-5.2431^{*} \\
(-1.85)\end{array}$ & $\begin{array}{c}-2.8146 \\
(-0.63)\end{array}$ \\
\hline Hansen ( $p$-value) & 0.294 & 0.187 & 0.238 & 0.126 & 0.287 & 0.316 \\
\hline AR (1) (p-value) & 0.006 & 0.003 & 0.006 & 0.009 & 0.006 & 0.002 \\
\hline AR (2) ( $p$-value) & 0.184 & 0.216 & 0.362 & 0.195 & 0.265 & 0.314 \\
\hline
\end{tabular}

Notes: We list the results of the current period and the three lagging periods considering the validity of the regression results. Investment perspective means the main explain variable is $E I$, and Cost perspective means the main explain variable is $P D F$. ***, ** and $*$ denote significance at the $1 \%, 5 \%$ and $10 \%$ levels, respectively. Figures in parenthesis are $t$-value.

Table 7. Results of threshold-effect tests.

\begin{tabular}{|c|c|c|c|c|c|}
\hline \multirow{2}{*}{\multicolumn{2}{|c|}{ Threshold variables }} & \multicolumn{2}{|c|}{ Single } & \multicolumn{2}{|c|}{ Double } \\
\hline & & \multirow{2}{*}{$\frac{F \text {-statistic }}{23.6400}$} & \multirow{2}{*}{$\frac{p \text {-Value }}{0.0300}$} & \multirow{2}{*}{$\frac{F \text {-statistic }}{6.2700}$} & \multirow{2}{*}{$\frac{p \text {-Value }}{0.2900}$} \\
\hline \multirow{3}{*}{$\begin{array}{l}\text { Investment per- } \\
\text { spective }\end{array}$} & $E I$ & & & & \\
\hline & $P G D P$ & 20.3900 & 0.0400 & 7.9200 & 0.5700 \\
\hline & $T L$ & 27.3800 & 0.0000 & 6.6000 & 0.8700 \\
\hline \multirow{3}{*}{ Cost perspective } & $P D F$ & 29.6900 & 0.0200 & 8.4800 & 0.4100 \\
\hline & $P G D P$ & 26.9700 & 0.0300 & 8.2800 & 0.5200 \\
\hline & $T L$ & 24.9500 & 0.0400 & 5.2300 & 0.7600 \\
\hline
\end{tabular}

Notes: Investment perspective means the main explain variable is $E I$, and Cost perspective means the main explain variable is $P D F$.

the low PGDP regime, the coefficient of EI is -0.0064 and statistically significant at the $1 \%$ level. When the value of $P G D P$ crosses the threshold, i.e. in the high PGDP ( $P G D P>3.5743)$, however, the coefficient of $E I$ equals to 0.0237 and statistically significant at the $1 \%$ level. Column 4 5 reports the estimation results from cost perspective. When the value of $P G D P$ is less than 3.7380, that is, under the low PGDP regime, the coefficient of $P D F$ is -0.0263 and statistically significant at the $1 \%$ level. When the value of PGDP crosses the threshold, i.e. in the high PGDP $(P G D P>3.7380)$, however, the coefficient of $P D F$ equals to 0.0971 and statistically significant at the $1 \%$ level. This suggests that environmental regulation has a negative impact on GTFP if it is below the $P G D P$ threshold, while the impact on GTFP is positive if it is above the $P G D P$ threshold.

Table 11 reports the estimation results of a single threshold model with $T L$ as the threshold variable. Column 2 3 reports the estimation results from 
Table 8 . Threshold estimators and the confidence intervals $($ level $=0.95)$.

\begin{tabular}{|c|c|c|c|c|c|}
\hline \multicolumn{3}{|c|}{ Investment perspective } & \multicolumn{3}{c|}{ Cost perspective } \\
\hline \multirow{3}{*}{$E I$} & Threshold estimator & 0.4721 & \multirow{2}{*}{ PDF } & Threshold estimator & 0.5087 \\
\cline { 2 - 3 } \cline { 5 - 6 } & Confidience intervals & {$[0.4196,0.4825]$} & & Confidience intervals & {$[0.4762,0.5151]$} \\
\hline \multirow{2}{*}{ PGDP } & Threshold estimator & 3.5743 & \multirow{2}{*}{ PGDP } & Threshold estimator & 3.7380 \\
\cline { 2 - 3 } \cline { 5 - 6 } & Confidience interval & {$[3.1191,3.9249]$} & & Confidience intervals & {$[2.8988,3.9378]$} \\
\hline \multirow{2}{*}{$T L$} & Threshold estimator & 15.1900 & \multirow{2}{*}{$T L$} & Threshold estimator & 15.5000 \\
\cline { 2 - 3 } \cline { 5 - 6 } & Confidience intervals & {$[13.4850,15.6200]$} & & Confidience intervals & {$[14.3850,16.1600]$} \\
\hline
\end{tabular}

Notes: Investment perspective means the main explain variable is $E I$, and Cost perspective means the main explain variable is $P D F$.

Table 9. Threshold model regression with environmental regulation as the threshold variable.

\begin{tabular}{|c|c|c|c|c|}
\hline Variables & $E I \leq 0.4721$ & $E I>0.4721$ & $P D F \leq 0.5087$ & $P D F>0.5087$ \\
\hline$E I$ & $\begin{array}{l}0.0305 \\
(1.26)\end{array}$ & $\begin{array}{c}0.1120 * * * \\
(3.52)\end{array}$ & & \\
\hline PDF & & & $\begin{array}{c}-0.0578^{* *} \\
(-2.12)\end{array}$ & $\begin{array}{c}0.0192 * * * \\
(3.46)\end{array}$ \\
\hline SIS & \multicolumn{2}{|c|}{$\begin{array}{c}0.0187 * * * \\
(3.61)\end{array}$} & \multicolumn{2}{|c|}{$\begin{array}{c}0.0044 * * * \\
(4.08)\end{array}$} \\
\hline Labor & \multicolumn{2}{|c|}{$\begin{array}{l}0.8789 \\
(1.29) \\
\end{array}$} & \multicolumn{2}{|c|}{$\begin{array}{c}0.9425^{*} \\
(1.82)\end{array}$} \\
\hline$R D$ & \multicolumn{2}{|c|}{$\begin{array}{c}0.1154^{* *} \\
(2.01)\end{array}$} & \multicolumn{2}{|c|}{$\begin{array}{c}0.1239 * * * \\
(4.86)\end{array}$} \\
\hline Market & \multicolumn{2}{|c|}{$\begin{array}{c}0.0088 * * * \\
(3.47)\end{array}$} & \multicolumn{2}{|c|}{$\begin{array}{c}0.0152 \\
(1.41) \\
\end{array}$} \\
\hline Urban & \multicolumn{2}{|c|}{$\begin{array}{c}0.1982 * \\
(1.85)\end{array}$} & \multicolumn{2}{|c|}{$\begin{array}{c}0.0907 * * \\
(2.13)\end{array}$} \\
\hline Constant & \multicolumn{2}{|c|}{$\begin{array}{c}-7.2303 * * * \\
(-9.56)\end{array}$} & \multicolumn{2}{|c|}{$\begin{array}{c}-7.8462 \\
(-1.42)\end{array}$} \\
\hline
\end{tabular}

Notes: $E I, P D F$ denotes the environmental regulation form investment and cost perspective, respectively. Column $2 \sim 3$ represents the result of regression when the main explain variable is $E I$. Column $4 \sim 5$ represents the result of regression when the main explain variable is $P D F * * *, * *$ and $*$ denote significance at the $1 \%, 5 \%$ and $10 \%$ levels, respectively. Figures in parenthesis are $t$-value.

investment perspective. When the value of $T L$ is less than 15.1900 , that is, under the lower TL regime, the coefficient of $E I$ is 0.0095 but insignificant. When the value of $T L$ crosses the threshold, i.e. in the higher TL regime $(T L>15.1900)$, however, the coefficient of $E I$ equals to 0.1025 and statistically significant at the $1 \%$ level. Column $4 \sim 5$ reports the estimation results from cost perspective. When the value of $T L$ is less than 15.5000 , that is, under the lower TL regime, the coefficient of $P D F$ is -0.0352 but insignificant. When the value of $T L$ crosses the threshold, i.e. in the higher TL regime $(T L>15.5000)$, however, the coefficient of $P D F$ equals to 0.0786 and statistically significant at the $1 \%$ level. This suggests that environmental regulation has no significant impact on GTFP if it is below the $T L$ threshold, while the impact on GTFP is positive if it is above the $T L$ threshold.

\section{Conclusions}

The marine economy plays an important role in the economic sustainability worldwide. We analyze the GTFP of marine economy by employing the panel data of 11 coastal provinces and cities in China from 2001 to 2016. Our main findings show that marine economy GTFP of China has an upward trend and the regional difference is significantly. Furthermore, environmental regulation from investment and cost perspective have a statistically positive effect on marine economy GTFP in the long term but not the short term, respectively. Subsequently, taking environmental regulation, the economic development level, and technological level as the threshold variables, respectively, there exists a single threshold effect of environmental regulation on the GTFP of the marine economy, and the driving mechanism changes from insignificant or inhibition to promotion. 
Table 10. Threshold model regression with $P G D P$ as the threshold variable.

\begin{tabular}{|c|c|c|c|c|}
\hline Variables & $P G D P \leq 3.5743$ & $P G D P>3.5743$ & $P G D P \leq 3.7380$ & $P G D P>3.7380$ \\
\hline$E I$ & $\begin{array}{c}-0.0064 * * * \\
(-3.16)\end{array}$ & $\begin{array}{c}0.0237 * * * \\
(2.98)\end{array}$ & & \\
\hline PDF & & & $\begin{array}{c}-0.0263 * * * \\
(-4.00)\end{array}$ & $\begin{array}{c}0.0971 * * * \\
(5.46)\end{array}$ \\
\hline SIS & \multicolumn{2}{|c|}{$\begin{array}{c}0.0044 * * * \\
(4.08)\end{array}$} & \multicolumn{2}{|c|}{$\begin{array}{c}0.0151^{* *} \\
(2.06)\end{array}$} \\
\hline Labor & \multicolumn{2}{|c|}{$\begin{array}{c}0.9425^{*} \\
(1.82)\end{array}$} & \multicolumn{2}{|c|}{$\begin{array}{c}0.9834 * * \\
(2.13)\end{array}$} \\
\hline$R D$ & \multicolumn{2}{|c|}{$\begin{array}{c}0.1239^{* * *} \\
(4.86)\end{array}$} & \multicolumn{2}{|c|}{$\begin{array}{c}0.1349 * * \\
(2.16)\end{array}$} \\
\hline Market & \multicolumn{2}{|c|}{$\begin{array}{c}0.0152 * * \\
(2.01)\end{array}$} & \multicolumn{2}{|c|}{$\begin{array}{c}0.0143^{*} \\
(1.82)\end{array}$} \\
\hline Urban & \multicolumn{2}{|c|}{$\begin{array}{c}0.0907 * \\
(1.83)\end{array}$} & \multicolumn{2}{|c|}{$\begin{array}{l}0.1645 \\
(1.04)\end{array}$} \\
\hline Constant & \multicolumn{2}{|c|}{$\begin{array}{c}-7.8462 * \\
(-1.82)\end{array}$} & \multicolumn{2}{|c|}{$\begin{array}{c}-8.2643 \\
(-1.36)\end{array}$} \\
\hline
\end{tabular}

Notes: $E I, P D F$ denotes the environmental regulation form investment and cost perspective, respectively. Column 2 3 represents the result of regression when the main explain variable is $E I$. Column $4 \sim 5$ represents the result of regression when the main explain variable is $P D F . * * * * *$ and $*$ denote significance at the $1 \%, 5 \%$ and $10 \%$ levels, respectively. Figures in parenthesis are $t$-value.

Table 11. Threshold model regression with TL as the threshold variable.

\begin{tabular}{|c|c|c|c|c|}
\hline Variables & $T L \leq 15.1900$ & $T L>15.1900$ & $T L \leq 15.5000$ & $T L>15.5000$ \\
\hline$E I$ & $\begin{array}{l}0.0095 \\
(0.92)\end{array}$ & $\begin{array}{c}0.1025^{* * *} \\
(3.14)\end{array}$ & & \\
\hline$P D F$ & & & $\begin{array}{c}-0.0352 \\
(-1.19)\end{array}$ & $\begin{array}{c}0.0786^{* * *} \\
(5.16)\end{array}$ \\
\hline SIS & \multicolumn{2}{|c|}{$\begin{array}{l}0.0653 \\
(1.34) \\
\end{array}$} & \multicolumn{2}{|c|}{$\begin{array}{l}0.0185 \\
(1.34) \\
\end{array}$} \\
\hline Labor & \multicolumn{2}{|c|}{$\begin{array}{c}0.8510^{* * *} \\
(4.06)\end{array}$} & \multicolumn{2}{|c|}{$\begin{array}{l}1.0070 \\
(8.24)\end{array}$} \\
\hline$R D$ & \multicolumn{2}{|c|}{$\begin{array}{c}0.0974 * * * \\
(4.42)\end{array}$} & \multicolumn{2}{|c|}{$\begin{array}{c}0.1161 * * * \\
(4.49)\end{array}$} \\
\hline Market & \multicolumn{2}{|c|}{$\begin{array}{c}0.0125^{* *} \\
(2.35)\end{array}$} & \multicolumn{2}{|c|}{$\begin{array}{c}0.0179 * * * \\
(3.71)\end{array}$} \\
\hline Urban & \multicolumn{2}{|c|}{$\begin{array}{c}0.1736 \\
(1.16) \\
\end{array}$} & \multicolumn{2}{|c|}{$\begin{array}{c}0.4740^{* *} \\
(2.15)\end{array}$} \\
\hline Constant & \multicolumn{2}{|c|}{$\begin{array}{c}-7.0178 * * * \\
(-10.73)\end{array}$} & \multicolumn{2}{|c|}{$\begin{array}{c}-8.6863 \\
(-1.18)\end{array}$} \\
\hline
\end{tabular}

Notes: $E I, P D F$ denotes the environmental regulation form investment and cost perspective, respectively. Column $2 \sim 3$ represents the result of regression when the main explain variable is $E I$. Column $4 \sim 5$ represents the result of regression when the main explain variable is $P D F$. TL represents the total number of marine economy research projects. $* * * * *$ and $*$ denote significance at the $1 \%, 5 \%$ and $10 \%$ levels, respectively. Figures in parenthesis are $t$-value.

We provide an important policy basis for how to achieve a win-win situation between the protection of marine ecology and the development of marine economy. Environmental regulation, if designed reasonably, is conducive to the sustainability of marine economy. Developed areas can achieve green transformation through strict environmental regulation. Less developed regions can encourage the development of the green industry to prevent the vicious cycle of pollution first and then harnessing. Finally, local governments should actively encourage innovation in the marine industry to achieve the sustainability of marine economy.

Our study also has a few limitations. Under the constraint of data availability, China's 11 provinciallevel regions are selected as the sample of this study. Owing to the small sample size, fewer decision-making 
units and input and output indicators are selected when GTFP is measured. We will dig this issue deeper when the data are available.

\section{Author Contributions}

Conceptualization, Q.L., and M.X.; methodology, T.J.; data curation, L.Q., and Q.M.; writing - original draft preparation, Q.M.; writing - review and editing, Q.M. and T; visualization, Y-q.T. All authors have read and agreed to the published version of the manuscript.

\section{Acknowledgements}

This research was funded by Liaoning social science planning fund (Grant No. L18BJY012), and Liaoning Shihua University Foundation China (Grant No. 2018XJJ-006). This study is funded by Research project on economic and social development of Liaoning Province (2022lslqnwzzkt-001).

\section{Conflicts of Interest}

The authors declare no conflict of interest.

\section{References}

1. PORTER M.E., VAN DER LINDE C. Toward a New Conception of the Environment-Competitiveness Relationship. Journal of Economic Perspectives, 9 (4), 97, 1995.

2. YANG C.H., TSENG Y.H., CHEN C.P. Environmental regulations, induced RD, and productivity: Evidence from Taiwan's manufacturing industries. Resource and Energy Economics, 34 (4), 514, 2012.

3. TANG L., LI K., JIA P. Impact of Environmental Regulations on Environmental Quality and Public Health in China: Empirical Analysis with Panel Data Approach. Sustainability, 12 (2), 623, 2020.

4. FENG T., DU H., LIN Z., ZUO J. Spatial spillover effects of environmental regulations on air pollution: Evidence from urban agglomerations in China. Journal of Environmental Management, 272, 110998, 2020.

5. YUAN B., XIANG Q. Environmental regulation, industrial innovation and green development of Chinese manufacturing: Based on an extended CDM model. Journal of Cleaner Production, 176, 895, 2018.

6. ZHANG X., YUE L., CHANG Y., WU Z., MUHAMMAD A.A. Assessment of technology vs environmental regulations in china based on dea malmquist model and porter hypothesis. Applied Ecology and Environmental Research, 16 (6), 7519, 2018.

7. ZEFENG M., GANG Z., XIAORUI X., YONGMIN S., JUNJIAO H. The extension of the Porter hypothesis: Can the role of environmental regulation on economic development be affected by other dimensional regulations? Journal of Cleaner Production, 203, 933, 2018.
8. National Development and Reform Commission of China. The 13th Five-Year Plan for National Marine Economic Development. Available online: http://www.mofcom.gov. cn/article/b/g/201709/20170902640261.shtml (accessed on 1 August 2020).

9. Ministry of ecology and environment of the people's republic of China. Bulletin on China's Marine Ecological Environment in 2018. Available online: https://hbdc.mee. gov.cn/hjyw/201905/t20190529 704849.shtml (accessed on 1 August 2020).

10. EDERINGTON J., MINIER J. Is environmental policy a secondary trade barrier? An empirical analysis. Canadian Journal of Economics/Revue canadienne d'économique, 36 (1), 137, 2003.

11. JAFFE A.B., PALMER K. Environmental Regulation and Innovation: A Panel Data Study. Review of Economics and Statistics, 79 (4), 610, 1997.

12. BRUNNERMEIER S.B., COHEN M.A. Determinants of environmental innovation in US manufacturing industries. Journal of Environmental Economics and Management, 45 (2), 278, 2003.

13. EIADAT Y., KELLY A., ROCHE F., EYADAT H. Green and competitive? An empirical test of the mediating role of environmental innovation strategy. Journal of World Business, 43 (2), 131, 2008.

14. BARBERA A.J., MCCONNELL V.D. The impact of environmental regulations on industry productivity: Direct and indirect effects. Journal of Environmental Economics and Management, 18 (1), 50, 1990.

15. DAM L., SCHOLTENS B. The curse of the haven: The impact of multinational enterprise on environmental regulation. Ecological Economics, 78, 148, 2012.

16. FORD J.A., STEEN J., VERREYNNE M.L. How environmental regulations affect innovation in the Australian oil and gas industry: going beyond the Porter Hypothesis. Journal of Cleaner Production, 84, 204, 2014.

17. HAMAMOTO M. Environmental regulation and the productivity of Japanese manufacturing industries. Resource and Energy Economics, 28 (4), 299, 2006.

18. ASANO T., MATSUSHIMA N. Environmental regulation and technology transfers. Can. J. Econ, 47, 889, 2012.

19. GIROD B., STUCKI T., WOERTER M. How do policies for efficient energy use in the household sector induce energy-efficiency innovation? An evaluation of European countries. Energy Policy, 103, 223, 2017.

20. CHAKRABORTY P., CHATTERJEE C. Does environmental regulation indirectly induce upstream innovation? New evidence from India. Research Policy, 46 (5), 939, 2017

21. COSTA-CAMPI M.T., GARCÍA-QUEVEDO J., MARTÍNEZ-ROS $\mathrm{E}$. What are the determinants of investment in environmental RD? Energy Policy, 104, 455, 2017.

22. LI K., LIN B. Impact of energy conservation policies on the green productivity in China's manufacturing sector: Evidence from a three-stage DEA model. Applied Energy, 168, 351, 2016.

23. CHEN S., GOLLEY J. 'Green' productivity growth in China's industrial economy. Energy Economics, 44, 89. 2014.

24. MASKIN E., QIAN Y., XU C. Incentives, Information, and Organizational Form. The Review of Economic Studies, 67 (2), 359. 2000.

25. LI H., ZHOU L.A. Political turnover and economic performance: the incentive role of personnel control in China. Journal of Public Economics, 89 (9), 1743, 2005. 
26. GREENSTONE M., HANNA R. Environmental Regulations, Air and Water Pollution, and Infant Mortality in India. American Economic Review, 104 (10), 3038, 2014.

27. RAMANATHAN R., RAMANATHAN U., BENTLEY Y. The debate on flexibility of environmental regulations, innovation capabilities and financial performance - A novel use of DEA. Omega, 75, 131, 2018.

28. BAITI N.S., NAGHAVI N., FAH B.C.Y. The Impact of Environmental Regulations, Corruption and Economic Freedom on Economic Growth: Empirical Evidence from China. International Journal of Economics and Finance, 9 (11), 92, 2017.

29. GHOSAL V., STEPHAN A., WEISS J.F. Decentralized environmental regulations and plant-level productivity. Business Strategy and the Environment, 28 (6), 998, 2019.

30. SHAO Y., XIAO C. Corporate tax policy and heterogeneous firm innovation: Evidence from a developing country. Journal of Comparative Economics, 47 (2), 470, 2019.

31. BORENSZTEIN E., OSTRY J.D. Accounting for China's Growth Performance. The American Economic Review, 86 (2), 224, 1996.

32. ZHAO M., LIU F., SUN W., TAO X. The Relationship between Environmental Regulation and Green Total Factor Productivity in China: An Empirical Study Based on the Panel Data of 177 Cities. International Journal of Environmental Research and Public Health, 17 (15), 5287, 2020.

33. LI K., LIN B. Measuring green productivity growth of Chinese industrial sectors during 1998-2011. China Economic Review, 36, 279, 2015.

34. STAVROPOULOS S., WALL R., XU Y. Environmental regulations and industrial competitiveness: evidence from China. Applied Economics, 50 (12), 1378, 2018.

35. JAFFE A.B., NEWELL R.G., STAVINS R.N., Environmental Policy and Technological Change. Environ. Resour. Econ, 22 (1), 41-70, 2002.

36. LIANG Z., CHIU Y., LI X., GUO Q., YUN Y. Study on the Effect of Environmental Regulation on the Green Total Factor Productivity of Logistics Industry from the Perspective of Low Carbon. Sustainability, 12 (1), 175, 2020.
37. LANOIE P., PATRY M., LAJEUNESSE R. Environmental regulation and productivity: testing the porter hypothesis. Journal of Productivity Analysis, 30 (2), 121, 2008.

38. ROMER P.M. Increasing Returns and Long-Run Growth. Journal of Political Economy, 94 (5), 1002, 1986.

39. ACS Z.J., BRAUNERHJELM P., AUDRETSCH D.B., CARLSSON B. The knowledge spillover theory of entrepreneurship. Small Business Economics, 32 (1), 15, 2009.

40. KOSEMPEL S. A theory of development and long run growth. Journal of Development Economics, 75 (1), 201, 2004.

41. ACEMOGLU D. Equilibrium Bias of Technology. Econometrica, 75 (5), 1371, 2007.

42. LONG X., WANG X., MENSAH C.N., WANG M., ZHANG J. Spatial and temporal heterogeneity of environmental efficiency for China's hotel sector: new evidence through metafrontier global MalmquistLuenberger. Environmental Science and Pollution Research International, 26 (26), 27534, 2019.

43. ARELLANO M., BOND S. Some Tests of Specification for Panel Data: Monte Carlo Evidence and an Application to Employment Equations. The Review of Economic Studies, 58 (2), 277, 1991.

44. HANSEN B.E. Threshold effects in non-dynamic panels: Estimation, testing, and inference. Journal of Econometrics, 93 (2), 345, 1999.

45. WANG Q. Fixed-Effect Panel Threshold Model using Stata. The Stata Journal, 15 (1), 121, 2015.

46. SUN P., SONG L.F. Calculation of China's marine environmental efficiency based on undesired super efficiency-Malmquist model. China Popul. Resour. Environ, 29, 43, 2019 [In Chinese].

47. LANOIE P., PATRY M., LAJEUNESSE R. Environmental regulation and productivity: testing the porter hypothesis. Journal of Productivity Analysis, 30 (2), 121, 2008.

48. XIA F., CHEN X., TANG H. The motive mechanism of seaward economic development and its improvement Path (In Chinese). China Soft S, 11, 139-152, 2019.

49. WANG X., FAN G., HU L. Marketization index of China's province: Neri report 2018. Economic Science Press, Beijing, China, 2019. 